\title{
Immunohistochemistry in diagnostic veterinary pathology: a critical review
}

\author{
Imuno-histoquimica na patologia veterinária diagnóstica: uma revisão crítica
}

Felipe Sueiro Ruiz'; Antonio Carlos Alessi²; Cristiano Aparecido Chagas'; Glauce Aparecida Pinto ${ }^{3}$; José Vassallo ${ }^{4}$

key words

Immunohistochemistry

Veterinary pathology

Tumor markers

\section{abstract}

Immunohistochemistry has become a practical and widely used tool for diagnosis in human pathology since the 70's. However, its application in veterinary diagnostic pathology has not been so common, especially due to the lack of specific antibodies. To overcome this drawback, antibodies which present cross reactivity with human and animal antigens have been applied. The purpose of the present study was to test the cross reactivity of some antibodies intended for the human pathology, which may be used in animal tissues, with the help of antigen retrieval and amplification systems. In the present study it was confirmed that many of the antibodies produced for use in human histopathology might be applied in veterinary pathology. Further studies are needed to increase the list of applicability of these antibodies to different animal species. It must be stressed that in this type of study some variables, such as clone of antibody, dilution, antigen retrieval method, and detection system, have to be evaluated. resumo

A técnica de imuno-histoquímica é usada na rotina diagnóstica e na pesquisa em patologia humana desde 1970, porém seu uso na patologia veterinária é relativamente recente, principalmente com objetivo diagnóstico. A maior dificuldade no uso da imuno-histoquímica na patologia veterinária tem sido a falta de anticorpos específicos para os tecidos animais. Na falta de anticorpos específicos para as espécies domésticas, a patologia veterinária freqüentemente faz uso de anticorpos que apresentam reatividade cruzada entre antígenos humanos e animais. O objetivo deste trabalho foi testar a reatividade cruzada de diversos anticorpos feitos para uso humano em tecido parafinado de algumas espécies animais, utilizando-se dos novos métodos de recuperação antigênica e amplificação da reação imuno-histoquímica. No presente estudo foi possível confirmar a aplicabilidade de que muitos anticorpos produzidos para diagnóstico imuno-histoquímico em patologia humana podem ser utilizados em patologia veterinária. Novos estudos são necessários a fim de se ampliar a lista de aplicabilidade desses anticorpos em diferentes espécies animais, levando sempre em consideração as variações de clones, diluições, métodos de recuperação antigênica e de revelação. unitermos

Imuno-histoquimica

Patologia veterinária

Marcadores tumorais

1. Post-graduate fellows of the Department of Anatomic Pathology, Faculdade de Ciências Médicas of Universidade Estadual de Campinas (UNICAMP)

2. Professor of the Department of Veterinary Pathology - Faculdade de Ciências Agrárias e Veterinárias of Universidade Estadual Paulista (UNESP//aboticabal).

3. Researcher of the Laboratory of Experimental Pathology, Centro de Atenção Integral à Saúde da Mulher (CAISM) of UNICAMP.

4. Associate professor of Pathology, Department of Anatomic Pathology, Faculdade de Ciências Médicas of UNICAMP. 


\section{Introduction}

Immunohistochemistry has become a practical and widely used tool for diagnosis in human pathology since the 70's. However, its application in veterinary diagnostic pathology has not been so common, especially due to the lack of specific antibodies. To overcome this drawback, antibodies which present cross reactivity with human and animal antigens have been applied. Other limitations of the method are represented by antigen masking by formalin fixation, reducing specific antigen-antibody binding ${ }^{(4,17,21)}$. In this respect, an extraordinary progress has been achieved with the production of a wide variety of monoclonal antibodies to epitopes resistant to formalin fixation, thanks to the hybridoma technology, with the use of antigen retrieval methods and powerful amplifying systems. These are generally streptavidin-biotin based systems (e. g., labelled streptavidin biotin $[\mathrm{LSAB}]$, catalysed signal amplification [CSA]) or polymer-based systems (e.g., EnVision), which may amplify the signal of immunohistochemical reaction up to 200 fold $^{(19)}$. All this has allowed cross reactivity of some antibodies produced for human antigens with formalinfixed, paraffin-embedded animal tissues.

Veterinary medicine has progressively improved its therapeutic spectrum, especially in oncology, demanding

\section{Tabela 1}

\begin{tabular}{lcc}
\hline Tissue & Animal & $\begin{array}{c}\text { Number } \\
\text { of cases }\end{array}$ \\
$\begin{array}{l}\text { Melanoma of the } \\
\text { skin }\end{array}$ & Dog & 4 \\
$\begin{array}{l}\text { Mastocytoma } \\
\text { TVT }\end{array}$ & Dog & 9 \\
Seminoma & Dog & 2 \\
Lymphoma & Dog & 1 \\
Cutaneous & Dog & 15 \\
histiocytoma & Dog & 10 \\
Neuroendocrine & Dog & 3 \\
tumor & Dog & 1 \\
Hemangiosarcoma & $\begin{array}{c}\text { Bruin (Ursus arctos } \\
\text { middendorffi) }\end{array}$ & 1 \\
Mesothelioma & $\begin{array}{c}\text { Dog, bovine, } \\
\text { monkey (sagüi una) }\end{array}$ & 10 \\
Reactive lymph node & Dog \\
Normal lung & 1 \\
\hline
\end{tabular}

TVT: transmissible venereal tumor. a more accurate diagnosis. This fact has brought to the attention of veterinary pathologists the need to improve the application of immunohistochemistry in their daily routine, following the tendency of human diagnostic pathology.

The purpose of the present study is to test the cross reactivity of some antibodies intended for the human pathology, which may be used in animal tissues, with the help of antigen retrieval and amplification systems.

\section{Material and methods}

All cases tested in the present study were obtained from the files of the Department of Veterinary Pathology, Faculdade de Ciências Agrárias e Veterinárias of Universidade Estadual Paulista (UNESP/Jaboticabal) and from the Laboratory of Experimental Pathology of Campinas, São Paulo, Brazil. Tissues used, animal source and number of cases are summarized in Table 1. The cases and species included in the present study corresponded either to those which presented diagnostic problems (more frequently), or to those which served as tests for future research projects.

\section{Immunohistochemistry}

Serial sections were placed on silanized slides and dewaxed. Antigen retrieval was performed after hydration and endogenous peroxidase blocking with $3 \% \mathrm{H}_{2} \mathrm{O}_{2}$ in a steamer (T-Fal ${ }^{\circledast}$, France) at $90^{\circ} \mathrm{C}$ for 30 minutes. The slides were then incubated overnight ( 18 hours) at $4^{\circ} \mathrm{C}$ with the primary antibodies specified in Table 2 . The detection systems for each primary antibody were used according to the suppliers' instructions (two polymer-based detection systems, EnVision [K1491; Dakocytomation, Carpenteria, CA, USA] and EnVision Plus [K4001, Dako], and a catalyzed signal amplification system, CSA [K1500; Dako], were used, as also listed in Table 2). Labeling was visualized with 3,3'diaminobenzidine (D-5637; Sigma, St. Luis, MO, USA) added to $\mathrm{H}_{2} \mathrm{O}_{2} 3 \%$ in phosphate-buffered saline ( $\mathrm{pH}$ 7.6). Positive controls consisted of human tissues known to be reactive for each marker. Negative controls were performed by replacing the primary antibody by bovine serum albumin (BSA 1\% in phosphate-buffered saline, pH 7.6) in the animal samples. Immunolabeling was evaluated microscopically.

\section{Results}

The description of immunolabeling for each marker is described in Table $\mathbf{3}$ and some examples are shown in Figures 1 to 8. 
Tabela 2

\section{Specification of antibodies used in the present study}

\begin{tabular}{|c|c|c|c|c|c|c|}
\hline Antibody & Supplier & Clone & Dilution & $\begin{array}{l}\text { Amplification } \\
\text { system }\end{array}$ & Tissue & Animal \\
\hline T-cell, CD3 & Dako & PC3/188A & $1: 50$ & EnVision & Lymph node & Dog \\
\hline T-cell, CD3 & Novocastra & PS1 & $1: 50$ & EnVision & Lymph node & Dog, bovine \\
\hline T-cell, CD8 & Novocastra & $1 \mathrm{~A} 5$ & 1:40 & EnVision & Lymph node & Monkey \\
\hline T-cell, CD8 & Novocastra & $1 \mathrm{~A} 5$ & $1: 800$ & CSA & Lymph node & Monkey \\
\hline T-cell, CD8 & Dako & C8/144B & $1: 50$ & EnVision & Lymph node & Monkey \\
\hline B-cell, BLA-36 & Novocastra & A2742 & $1: 50$ & CSA/Envision & Lymph node & Dog, bovine \\
\hline B-cell, CD79a & Dako & HM57 & $1: 50$ & CSA/EnVision & Lymph node & Dog \\
\hline CD117, c-kit & Dako & Polyclonal & $1: 50$ & EnVision & Mastocytoma & Dog \\
\hline CD31 & Dako & $\mathrm{JC} 70 \mathrm{~A}$ & 1:10 & EnVison & $\begin{array}{l}\text { Hemangiosar- } \\
\text { coma }\end{array}$ & Dog \\
\hline Lysozyme & Dako & Polyclonal & 1:400 & EnVision & $\begin{array}{c}\text { Cutaneous } \\
\text { histiocytoma }\end{array}$ & Dog \\
\hline Myeloperoxidase & Dako & Polyclonal & $1: 400$ & Envision & $\begin{array}{l}\text { Cutaneous } \\
\text { histiocytoma }\end{array}$ & Dog \\
\hline $\begin{array}{l}\text { Pancytokeratin, } \\
\text { AE1/AE3 }\end{array}$ & Dako & Polyclonal & $1: 50$ & EnVision & Skin & Dog \\
\hline NSE & Dako & $\begin{array}{c}\text { BBS/NC/VI } \\
\text { H14 }\end{array}$ & $1: 100$ & EnVision & $\begin{array}{l}\text { Neuroendocrine } \\
\text { tumor }\end{array}$ & Dog \\
\hline Sinaptofisin & Dako & Polyclonal & $1: 50$ & EnVision & $\begin{array}{l}\text { Neuroendocrine } \\
\text { tumor }\end{array}$ & Dog \\
\hline S-100 protein & Dako & Polyclonal & $1: 800$ & EnVision & Melanoma & Dog \\
\hline $\begin{array}{l}\text { Melanocytic antigen, } \\
\text { HMB45 }\end{array}$ & Dako & HMB35 & 1:10 & EnVision & Melanoma & Dog \\
\hline Vimentin & Dako & V9 & $1: 50$ & EnVision & $\begin{array}{l}\text { Melanoma, } \\
\text { mesothelioma }\end{array}$ & Dog, bear \\
\hline PLAP & Dako & $8 \mathrm{~A} 9$ & $1: 50$ & EnVision & Seminoma & Dog \\
\hline TTF-1 & Dako & $8 G 7 G 3 / 1$ & $1: 50$ & EnVision Plus & Lung & Dog \\
\hline p-53 protein & Novocastra & $\begin{array}{c}\text { CM-1, } \\
\text { polyclonal }\end{array}$ & $1: 50$ & EnVision & Lymphoma & Dog \\
\hline c-myc protein & Dako & 9E11 & $1: 50$ & EnVision Plus & TVT & Dog \\
\hline $\begin{array}{l}\text { Proliferation antigen, } \\
\text { Ki-67 }\end{array}$ & $\begin{array}{l}\text { Immuno- } \\
\text { tech }\end{array}$ & MIB-1 & $1: 50$ & EnVision Plus & TVT & Dog \\
\hline $\begin{array}{l}\text { Proliferation antigen, } \\
\text { Ki-S-5 }\end{array}$ & Dako & Ki-S-5 & $1: 50$ & EnVision Plus & TVT & Dog \\
\hline $\begin{array}{l}\text { Proliferation antigen, } \\
\text { Ki-67 }\end{array}$ & Novocastra & MM-1 & $1: 50$ & EnVision Plus & TVT & Dog \\
\hline PCNA & Dako & PC10 & $1: 100$ & EnVision & Mastocytoma & Dog \\
\hline PCNA & Novocastra & PC10 & 1:100 & EnVision & Mastocytoma & Dog \\
\hline
\end{tabular}

NSE: neuron specific enolase; PLAP: placental alkaline phosphatase; TTF-1: thyroid transcription factor; TVT: transmissible venereal tumor; PCNA: proliferating cell nuclear antigen. 
Tabela 3 Specific immunolabeling for each marker used in this study

\begin{tabular}{|c|c|c|c|}
\hline Antibody & Supplier & $\begin{array}{c}\text { Number of } \\
\text { positive cases }\end{array}$ & Immunolabeling \\
\hline T-cell, CD3 & Dako & $5 / 5$ & $\begin{array}{l}\text { Intense, membrane of small lymphocytes in paracortical } \\
\text { areas }\end{array}$ \\
\hline T-cell, CD3 & Novocastra & $5 / 5$ & $\begin{array}{l}\text { Intense, membrane of small lymphocytes in paracortical } \\
\text { areas }\end{array}$ \\
\hline T-cell, CD8 & Novocastra & $8 / 8$ & $\begin{array}{l}\text { Weak when the Envision detections system was used. In- } \\
\text { tense with CSA detection system, membrane of scattered } \\
\text { small lymphocytes in follicles and paracortical areas }\end{array}$ \\
\hline T-cell, CD8 & Dako & $0 / 8$ & Not reactive \\
\hline B-cell, BLA-36 & Novocastra & $10 / 10$ & $\begin{array}{l}\text { Moderate, membrane of small lymphocytes and blasts in } \\
\text { follicles and scattered lymphoid cells in paracortical areas }\end{array}$ \\
\hline B-cell, CD79a & Dako & $10 / 10$ & $\begin{array}{c}\text { Intense, transmembrane of small lymphocytes and blasts } \\
\text { in follicles and scattered lymphoid cells in paracortical } \\
\text { areas }\end{array}$ \\
\hline CD117, c-kit & Dako & $9 / 9$ & Variable, cytoplasm of neoplastic mast cells, Golgi pattern \\
\hline CD31 & Dako & $1 / 1$ & Moderate, cytoplasm of hemangiosarcoma cells \\
\hline Lysozyme & Dako & $10 / 10$ & Intense, cytoplasm of histiocytes and granulocytes \\
\hline Myeloperoxidase & Dako & $10 / 10$ & Intense, cytoplasm of granulocytes in a granular pattern \\
\hline $\begin{array}{l}\text { Pancytokeratin, } \\
\text { AE1/AE3 }\end{array}$ & Dako & $4 / 4$ & Intense, cytoplasm of epithelial cells \\
\hline NSE & Dako & $4 / 4$ & Moderate, cytoplasm of neuroendocrine cells \\
\hline Sinaptofisin & Dako & $3 / 3$ & Moderate, cytoplasm of neuroendocrine cells \\
\hline S-100 protein & Dako & $5 / 5$ & Intense, cytoplasm of mesenchymal cells \\
\hline $\begin{array}{l}\text { Melanocytic antigen, } \\
\text { HMB45 }\end{array}$ & Dako & $0 / 4$ & Not reactive \\
\hline Vimentin & Dako & $5 / 5$ & Intense, cytoplasm of mesenchymal cells \\
\hline PLAPH & Dako & $1 / 1$ & Moderate, cytoplasm of seminoma cells \\
\hline TTF-1 & Dako & $1 / 1$ & Intense, nuclei of pneumocytes \\
\hline p-53 protein & Novocastra & $8 / 8$ & Intense, nuclei of neoplastic lymphoid cells \\
\hline c-myc & Dako & $2 / 2$ & Variable; nuclei of TVT cells \\
\hline $\begin{array}{l}\text { Proliferation antigen, } \\
\text { Ki-67 }\end{array}$ & Immunotech & $10 / 10$ & Intense, nuclei of TVT cells \\
\hline $\begin{array}{l}\text { Proliferation antigen, } \\
\text { Ki-S-5 }\end{array}$ & Dako & $10 / 10$ & Intense; nuclei of TVT cells \\
\hline $\begin{array}{l}\text { Proliferation antigen, } \\
\text { Ki-67 }\end{array}$ & Novocastra & $10 / 10$ & Intense; nuclei of TVT cells \\
\hline PCNA & Dako & $10 / 10$ & Variable, nuclei of lymphocytes and mast cells \\
\hline PCNA & Novocastra & $10 / 10$ & Variable, nuclei of lymphocytes and mast cells \\
\hline
\end{tabular}

NSE: neuron specific enolase; PLAPH: placental alkaline phosphatase; TTF-1: thyroid transcription factor; TVT: transmissible venereal tumor; PCNA: proliferating cell nuclear antigen. 


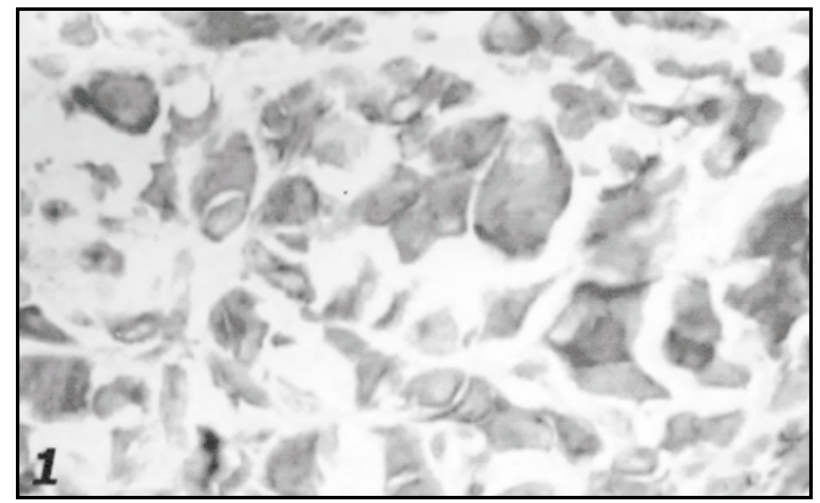

Figure 1 - Mesothelioma, anti-vimentin, cytoplasm stainig ( x 1.000)

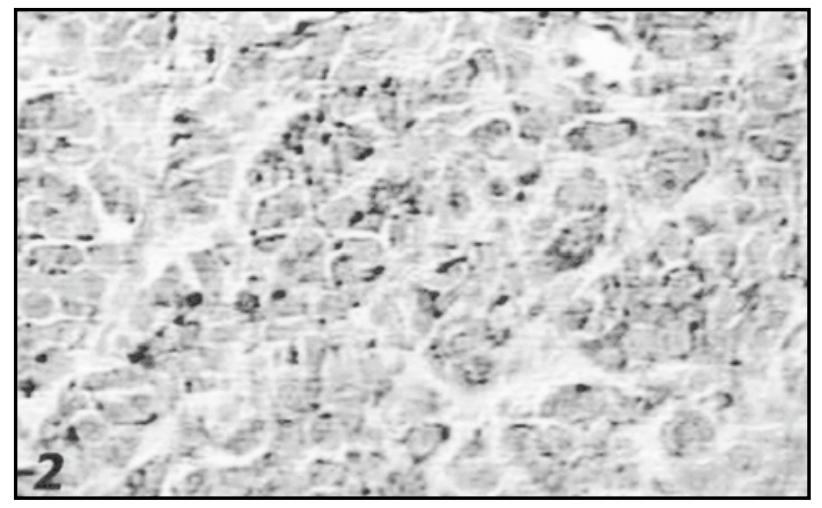

Figure 2 - Neuroendocrine carcinoma, anti-neuron specific enolase (NSE), cytoplasm staining (x 800)

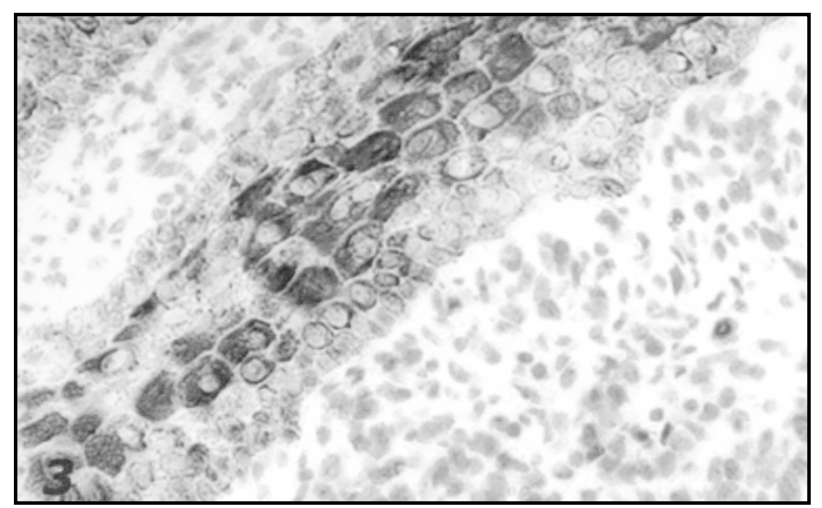

Figure 3 - Skin, anti-cytokeratin AE1/AE3, cytoplasm staining (x 800)

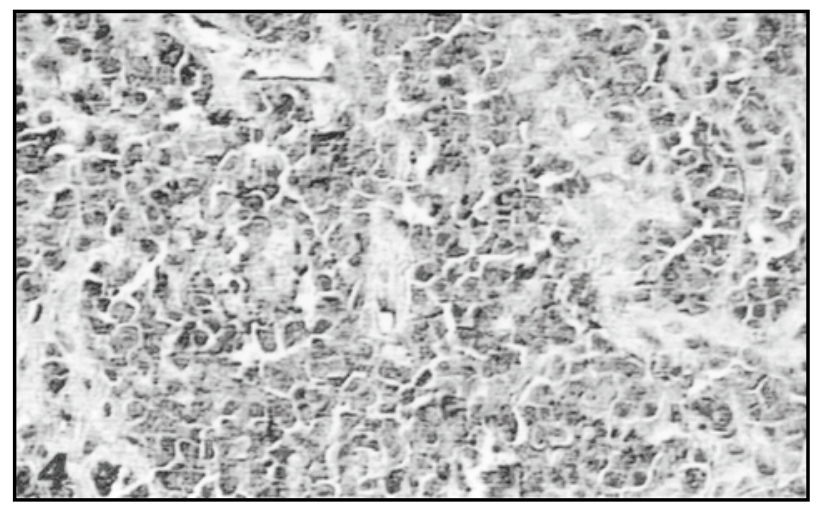

Figure 4 - Melanoma, anti-S100 protein, cytoplasm staining, (x 400)

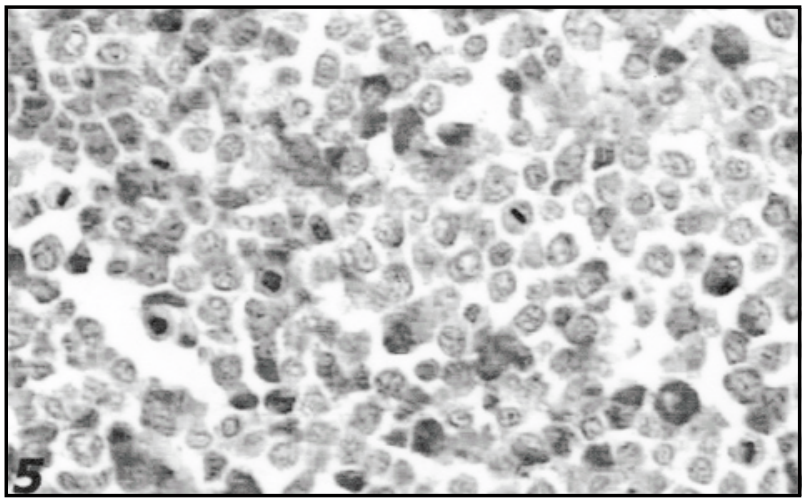

Figure 5 - Seminoma, anti-placental alkaline phosphatase (PLAP), cytoplasm staining $(x 800)$

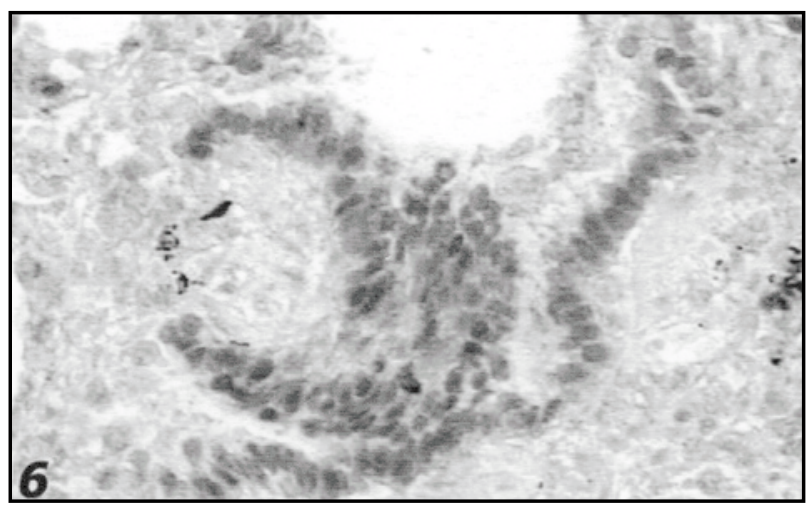

Figure 6 - Lung (pneumocytes), anti-thyroid transcription factor-1 (TTF1), nuclear staining $(x 800)$

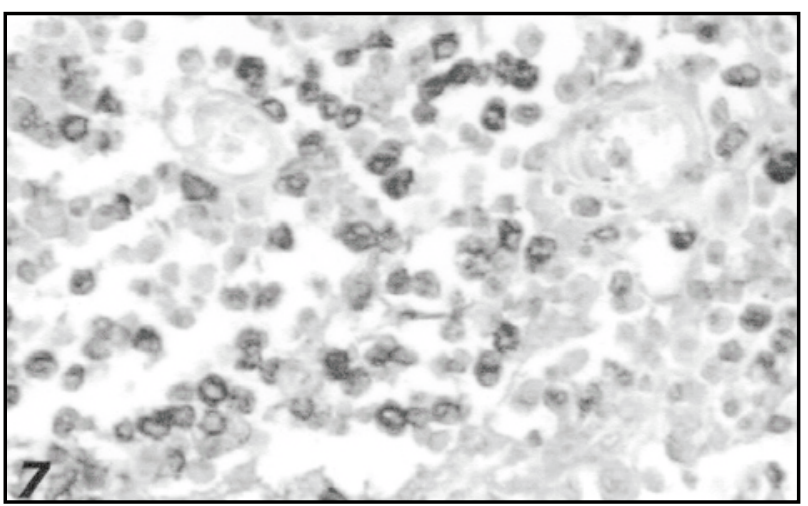

Figure 7 - Cutaneous histiocytoma, anti-lysozyme, cytoplasm staining (x 800)

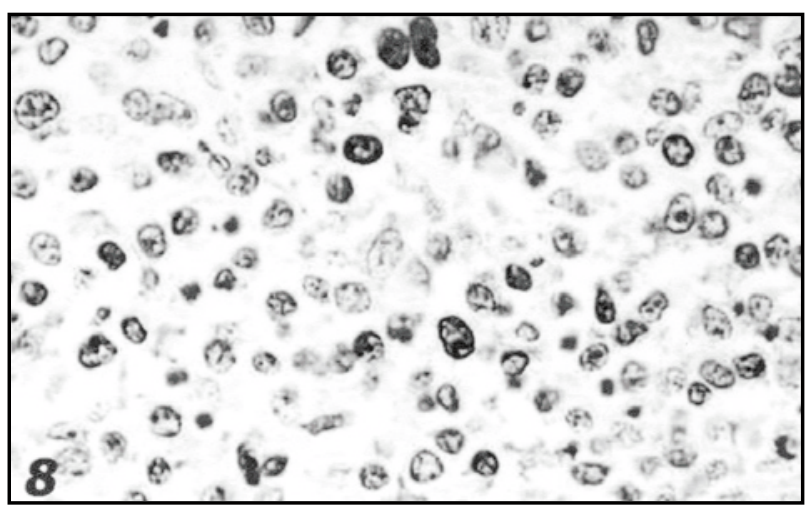

Figure 8 - Mastocytoma, anti-proliferation marker Ki-67, nuclear staining (x 1.000) 


\section{Discussion}

Most antibodies developed for animals are suitable for fresh tissue and have a limited application in routine veterinary histopathology. The most frequently used immunomarkers for animals in the routine diagnosis are polyclonal, as they contain antibodies to a wider range of epitopes, increasing sensitivity of the method, sometimes in detriment of specificity. Antigen retrieval techniques, especially the heat-induced ones, have been widely used in human pathology since the 80 's, allowing reliable immunodetection of epitopes distorted by formalin fixation $^{(4,17,21)}$. These techniques have proven efficiency in routine veterinary pathology, permitting the utilization of a wider spectrum of markers, including monoclonal and those intended for human use, as shown by our results.

The polymer-based detection systems (e. g., EnVision and EnVision Plus) have increased sensitivity of immunoreactions and reduced one of its steps ${ }^{(19)}$. In our study, this system has shown good results for most antibodies. However, in some cases, a signal amplification was needed (e. g., for the pan-B marker CD79a, as previously demonstrated by Sueiro et al.) $)^{(22)}$. The catalyzed signal amplification system is very sensitive ${ }^{(19)}$, but may result in unacceptable background staining. To overcome this adverse effect, thorough washing between the steps of the reaction and, sometimes, the over dilution of the primary antibody are necessary.

Antibodies to pancytokeratin AE1/AE3, neuron specific enolase (NSE), synaptofisin (SNF), S-100 protein and vimentin were previously described as showing cross reactivity in different animal species ${ }^{(17,20,31)}$. Antibody to AE1/AE3 showed specificity in epithelial cells in our cases. The use of heat-induced epitope retrieval (HIER) and the polymer-based detection system were efficient, allowing a higher dilution of primary antibody and replacing the more imprecise method of enzymatic digestion, as previously reported ${ }^{(20)}$.

The melanocytic antigen (Dako, clone HMB45) did not react in any test performed, using the same procedures described by Sulaimon et al. ${ }^{(27)}$.

The antibodies to NSE and SNF also showed specific labeling, but in lesser intensity than the positive controls. This reinforces the need of testing different conditions of dilutions and reactions to adapt the use of antibodies for use in different animal species. Antibody to $S-100$ proteins showed intense cytoplasmic reactivity, accompanied by scattered nuclear positivity ${ }^{(24,26)}$. Strong labeling for vimentin in a case of mesotheliona of bruin (Ursus arctos middendorffi) demonstrates the widespread preservation of this antigen in various species.

Lymphoid markers are largely used in human pathology and have been shown to cross react in various animal

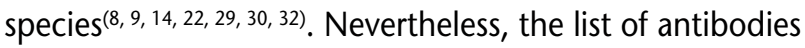
for use in veterinary pathology is still small. In 1993, Jones et al.(7) demonstrated cross reactivity of the antibody to $C D 3$ in frozen sections of various domestic species, such as horses, bovines, pigs and chicken. This was later confirmed in formalin-fixed, paraffin-embedded material, using different detection and amplification methods ${ }^{(8)}$. In our cases, CD3 was expressed in strong intensity in cell membrane of $T$ lymphocytes of the species tested. Even the use of HIER and the polymer-based detection system did not allow higher dilution of the primary antibody, but no background unspecific reactivity was seen. Antibody to CD8 for use in animals is available only for frozen tissue ${ }^{(15)}$. The anti-human CD8 showed satisfactory immunolabeling in a hyperplastic monkey (sagüi una) lymph node. Another clone used (Dako, clone C8/144B) did not react, what stresses the need to test different suppliers and clones when the use in other species is intended. The cross reactivity of the pan-B antibodies to CD79a and BLA-36 has already been demonstrated ${ }^{(8)}$. In our cases, reactivity for CD79a was more intense than for BLA-36, but a more sensitive detection system (CSA) was necessary for the first. A faint positivity in the muscular layer of blood vessels was also seen in specimens stained for CD79a, in accordance with previous reports ${ }^{(2)}$.

Antibodies to lysozyme and myeloperoxidase labeled intensely histiocytes and myeloid cells of canine lymph nodes. The usefulness of these markers to differentiate histiocytic and myeloid neoplasms from lymphoma and other small cell neoplasia was demonstrated elsewhere ${ }^{(22)}$.

The thyroid transcription factor (TTF-1) had already been shown to cross react with normal and neoplastic canine thyroid ${ }^{(16)}$. The placental alkaline phosphatase (PLAPH) was not previously described in animal tumors. In our study, both were demonstrated in strong intensity in canine tissue, as compared with the positive human controls.

Reactivity of CD117/c-kit in cell membrane and cytoplasm was intense in our cases of canine mastocytoma, as previously described ${ }^{(10,18,25)}$, confirming its utility in the identification of difficult cases. The polyclonal antibody to the p53 protein (Novocastra, clone CM1) showed strong nuclear reactivity, confirming the applicability of this marker in research and diagnostic veterinary pathology ${ }^{(5,}$ 
$6,10,11,18,22,23)$. Immunoexpression of c-myc was strong in the nuclei of the case of canine transmissible venereal tumor (TVT) tested in this study, corroborating previous reports $^{(1,35)}$. This protein has also been demonstrated in canine breast tumors ${ }^{(6)}$.

Amino acid sequences of proliferating cell nuclear antigen (PCNA) present high homology among mammalians, and also in superior vegetal ${ }^{(28)}$. In our cases, nuclear reactivity for PCNA was strong, with faint cytoplasmic staining in mitotic cells ${ }^{(12,34)}$. In humans and animals, detection of the antigen Ki-67 has proven superior to PCNA in evaluation of proliferation index ${ }^{(3,13,33)}$. In our experience, the best clone for application in canine pathology was MIB-1, as compared with MM-1 and Ki-S-5.

\section{Conclusion}

In the present study it was confirmed that many of the antibodies produced for use in human histopathology might be applied in veterinary pathology. Further studies are needed to increase the list of applicability of these antibodies to different animal species. It must be stressed that in this type of study, some variables, such as clone of antibody, dilution, antigen retrieval method, and detection system, have to be evaluated.

\section{Referências}

I. AMARIGLIO, E. N. et al. Identity of rearranged LINE/c-MYC junction sequences specific for the canine transmissible venereal tumor. Proc Nat Acad Sci USA, v. 88, p. 8136-9, 1991.

2. CHU, P. G.; ARBER, D. A. CD79: a review. Appl Immunohistochem Mol Morphol, v. 9, n. 2, p. 97-106, 2001.

3. FOURNEL-FLEURY, C. Growth fractions in canine non-Hodgkin's lymphomas as determined in situ by the expression of the Ki-67 antigen. J Comp Pathol, v. I 17, p. 61-72, 1997.

4. FROST, A. R.; SPARKS, D.; GRIZZLE, W. E. Methods of antigen recovery vary in their usefulness in unmasking specific antigens in immunohistochemistry. Appl Immunohistochem Mol Morphol, v. 8, n. 3, p. 236-43, 2000.

5. GAMBLIN, R. M.; SAGARTZ,J. E.; COUTO, C. G. Overexpression of p53 tumor suppressor protein in spontaneously arising neoplasms of dogs. Am J Vet Res, v. 58, p. 857-63, 1997.

6. INOUE, M.; SHIRAMIZU, K. Immunohistochemical detection of p53 and c-myc proteins in canine mammary tumours. J Comp Pathol, v. 120, n. 2, p. 169-75, 1999.

7. JONES, M. et al. Detection of T and B cells in many animal species using cross-reactive anti-peptide antibodies.J Immunol, v. I 50, n. 12, p.5429-35, 1993.

8. KELLEY, L. C. et al. Detection of equine and bovine T- and Blymphoctytes in formalin-fixed paraffin-embedded tissues. Vet Immunol Immunopathol, v. 57, p. 187-200, 1997.

9. KELLEY, L. C.; MAHAFFEY, E. A. Equine malignant lymphomas: morphologic and immunohistochemical classification. Vet Pathol, v. 35, p. 24I-52, 1998.

10. LONDON, C. A. et al. Expression of stem cell factor receptor (c-kit) by the malignant mast cells from spontaneous canine mast cell tumours. J Comp Pathol, v. I I 5, p. 399-4I4, 1996.

I I. LONDON, C. A. et al. Spontaneous canine mast cell tumors express tandem duplications in the proto-oncogene c-kit. Exp Hematol, v. 27, p. 689-97, 1999.

12. MADEWELL, B, R. Cellular proliferation in tumors: a review of methods, interpretation, and applications. J Vet Intern Med, v. I5, p. 334-40, 2001 .

13. MELLO, E. S.; ALVES,V. A. F. Marcadores de proliferação celular.
In: ALVES, V. A. F:; BACCHI, C. E.; VASSALLO, J. Manual de Imuno-histoquímica. São Paulo: Sociedade Brasileira de Patologia, 1999. p. 182-94.

I4. MILNER, R. J. et al. Immunophenotypic classification of canine malignant lymphoma on formalin-fixed paraffin waxembedded tissue by means of CD3 and CD79a cell markers. Onderstepoort J Vet Res, v. 63, p. 309-13, 1996.

15. MOORE, P. F. et al. Monoclonal antibodies specific for canine CD4 and CD8 define functional T-lymphocyte subsets and high-density expression of CD4 by canine neutrophils. Tissue Antigens, v. 40, n. 2, p.75-85, 1992.

16. RAMOS-VARA, J. A. et al. Immunohistochemical detection of thyroid transcription factor-I, thyroglobulin, and calcitonin in canine normal, hyperplastic, and neoplastic thyroid gland. Vet Pathol, v. 39, n. 4, p. 480-7, 2002.

17. RHIND, S. M. Veterinary oncological pathology: current and future perspectives. Vet J, v. 163, p. 7-18, 2002.

18. ROGUERA, M. J. B. et al. Canine mast cell tumors express stem cell factor receptor. Am J Dermatopathol, v. 22, n. I, p. 49-54, 2000.

19. SABATTINI, E. et al. The EnVision system: a new immunohistochemical method for diagnostics and research. Critical comparison with the APAAP, chemMate, CSA, LABC, and SABC techniques. J Clin Pathol, v. 5 I, n. 7 , p.506-II, 1998.

20. SANDUSKY, G. E.; WIGHTMAN, K. A.; CARLTON, W. W. Immunocytochemical study of tissues from clinically normal dogs and of neoplasms, using keratin monoclonal antibodies. Am J Vet Res, v. 52, n. 4, p. 613-8, 1991.

2।. SHI, S.; COTE, R. J.; TAYLOR, C. R. Antigen retrieval immunohistochemistry and molecular morphology in the year 200 I. Appl Immunohistochem Mol Morphol, v. 9, n. 2, p. 107-|6, 200।.

22. SUEIRO, F.A. R.;ALESSI,A. C.;VASSALLO, J. Canine lymphomas: a morphological and immunohistochemical study of 55 cases, with observations on p53 immunoexpression.J Comp Pathol, v. I31, p. 207- I3, 2004.

23. SUEIRO, F.A. R.; ALESSI,A. C.;VASSALLO, J. Immunoexpression 
of p53 in canine lymphomas. In: INTERCONTINENTAL CONGRESS OF PATHOLOGY, 2004. Foz do Iguaçu. Revista Médica do Paraná, v. 62, n. especial, p. 186, 2004.

24. SUEIRO, F.A. R.; DOMINGUES, L. M.; CHAGAS, C.A. Aplicação da imunoistoquímica no diagnóstico de melanomas caninos. In: XXIV CONGRESSO BRASILEIRO DE PATOLOGIA, 2003. Florianópolis.Jornal Brasileiro de Patologia - Suplemento Científico, v. 39, n. I, p. II3, 2003.

25. SUEIRO, F. A. R.; METZE, K. Mastocitoma canino: avaliação da relação entre morfologia, maturação granular, proliferação e imunoexpressão da oncoproteína c-kit em 28 casos. In: I SIMPÓSIO DE ONCOLOGIA VETERINÁRIA, 2004. São Paulo. Anais eletrônicos. São Paulo, 2004.

26. SUEIRO, F.A. R.:VASSALLO,J.Sarcoma epitelióide em um golden retriever: relato de caso. In: I SIMPÓSIO DE ONCOLOGIA VETERINÁRIA, 2004. São Paulo. Anais eletrônicos. São Paulo, 2004.

27. SULAIMON, S. S.; KITCHELL, E. J.; EHRHART, E. J. Immunohistochemical detection of melanoma-specific antigens in spontaneous canine melanoma. J Comp Pathol, v. 12, p. 162-8, 2002.

28. SUZUKA, I. et al. Gene for proliferating-cell nuclear antigen (DNA polymerase delta protein) is present both in mammalian and higher plant genomes. Proc Nat Acad Sc, v. 86, p. $3189-93,1989$.
29. THOMAS, R. et al. Molecular cytogenetic analysis of a novel high-grade canine T-lymphoblastic lymphoma demonstrating co-expression of CD3 and CD79a cell markers. Chromosome Research, v. 9, p. 649-57, 2001.

30. VALLI, V. E. et al. Histological classification of hematopoietic tumors of domestic animals. Washington, DC:Armed Forces Institute of Pathology, 2002.

31.WALTER,J.A cytokeratin profile of canine epithelial skin tumours. J Comp Pathl, v. I22, n. 4, p. 278-87, 2000.

32. WALTON, R. M.; HENDRICK, M. J. Feline Hodgkin's-like lymphoma: 20 cases (1992-1999). Vet Pathol, v. 38, p. 504II, 200 I.

33. ZUCCARI, D. A. P. C. et al. A imunoexpressão do Ki-67 e da caspase 3 nas neoplasias mamárias em cadelas. In: I SIMPÓSIO DE ONCOLOGIA VETERINÁRIA, 2004. São Paulo. Anais eletrônicos. São Paulo, 2004.

34.ZUCCARI, D.A.P.C. et al.A relação do PCNA com o diagnóstico e a ulceração nas neoplasias mamárias em cadelas. In: I SIMPÓSIO DE ONCOLOGIA VETERINÁRIA, 2004. São Paulo. Anais eletrônicos. São Paulo, 2004.

35. ZUCCARI, D. A. P. C. et al. Imunodetecção da expressão da oncoproteína c-myc em tumor venéreo transmissível (TVT). In: XI ENCONTRO NACIONAL DE PATOLOGIA VETERINÁRIA, 2003. Botucatu. XI Encontro Nacional de Patologia Veterinária - Resumos. 2003. p. 254. 